\title{
On the Way to Improve the Employability of College Students in the New Era \\ Li Qitao*
}

Heilongjiang Bayi Agricultural University, Daqing City, Heilongjiang Province, China

DOI: $10.36347 /$ sjahss.2020.v08i05.001

| Received: 21.04.2020 | Accepted: 01.05.2020 | Published: 06.05.2020

*Corresponding author: Li Qitao

Abstract

Review Article

In the new era, China has taken new measures in the employment of College Students, Made in China, One Belt and One Road, network power and other policy promotion. In the new era, China's economy is booming, and the employability of college students is particularly important. Considering the impact of the economic downward pressure and the superposition of the epidemic, it is expected that this year's college graduates will face an extremely grim and complex employment situation. The enhancement of college students' employability is of great practical significance for individuals or enterprises and even for economic development, which is also of great significance for improving the economic construction of the motherland. The author mainly according to the new era under the background of university students' employment situation, from the university students' employment forms and problems were analyzed, and further expounds college students' employment ability is affected some of the key reasons, according to the reality put forward three measures to promote university students' employment ability.

Keywords: New era; Contemporary college student; Employability.

Copyright @ 2020: This is an open-access article distributed under the terms of the Creative Commons Attribution license which permits unrestricted use, distribution, and reproduction in any medium for non-commercial use (NonCommercial, or CC-BY-NC) provided the original author and source are credited.

\section{INTRODUCTION}

College graduates are valuable human resources in our country. Promoting full employment of college graduates is an important condition for improving people's livelihood and maintaining overall social stability, as well as an important guarantee for achieving sustained and healthy economic development [1]. The state attaches great importance to the employment of college students, and the government and the central government have put forward many measures for college students, including precise assistance, innovation and entrepreneurship. For college students, innovation and entrepreneurship is in line with the high expectations of the party and the government [2]. However, under the training of college students, especially their employability, colleges and universities should combine with the new era and give different plans to improve the employability of students with the idea of different ways and the same goal, which does not fail to meet the expectations of education [3].

\section{Forms and difficulties of college students' employment in the new era}

The form of employment of college students is particularly tense in recent years, the overall situation is not optimistic. First, there will be 8.74 million college graduates in 2020. At present, it is a critical period for college graduates to find jobs. Under the impact of the economic downward pressure and the COVID 19 epidemic, college graduates have more difficulties in finding jobs and the employment situation is complicated and grim [4]. The second factor is the education thought that for a long time emphasizes the theory rather than the practice, which makes the college students' employment practice ability show a certain lack, and it is also limited when improving, which makes the college students' employment difficult. The third factor is that modern college students' employment thoughts show a "high-minded and low-skilled" situation. When they are employed, they prefer jobs with "more money and less work", but the reality is often "less money and more work and less home". The fourth factor is that China's current job market is less perfect, part of the employment information exchange is not timely, part of the employment channels are relatively narrow [5].

The employment of college students also shows part of the problem, led by the lack of goals. Fresh graduate is in obtain employment, the unit that does not have specific understanding to obtain employment direction and obtain employment, obtain 
employment shows blindness, do not have specific thinking to ideal post and working direction. To be specific, the current graduates in the job market, students can only take a resume according to the direction of the recruiters around, they need to work, they want to fight for the direction of no clear answer, go with the crowd but true goal, make the job search lost. The second problem is that the employment objective is relatively simple. Some college students have a clear goal when they get employed, and they spend time and hard work on the way to achieve it. These students often master certain knowledge in a specific field, but their goal of employment is single. The third problem is regional constraints. Some employment units prefer to recruit students from local sources. Due to the limitations of their major and the lack of understanding of regional requirements and the lack of occupational analysis ability, students spend too much time in the best job-hunting time to seek jobs in other places, and then they miss other excellent employment units. Finally, they have nowhere to go. The fourth problem is that students' understanding of social phenomena is not clear enough. Part of college students concentrate on a thing that oneself like, or is very positive for specialized course learning, or immersed in a student cadre, games, travel, in the form of these interests occupy them a lot of time, for many jobs function concept is very fuzzy, don't know the actual situation of jobs. Many college students have a vague concept of the job and the society when they apply for a job. They have a blank mind, which may lead to problems in their employment [6].

\section{Important ways to improve college students' employability in the new era}

According to the above analysis, the problems and some influencing factors in the employment of college students in the new era reflect the current situation that is in urgent need of change. The author proposes the following three measures to improve the employability of college students [7].

First, improve the employment guidance system for college students, encourage students to conduct self-assessment of college students' employment, and help guide students to better realize their career planning. College students' employment guidance mechanism in the core content is to help students make career planning, students should be based on the characteristics of professional and their own will, in the early life planning has the certain understanding, colleges and universities teaching plan should be according to the situation to carry on the design, teaching and career planning to carry on the organic fusion, in the daily courses among the college students' career planning in the evening. When students understand their career, they need to understand the current employment situation first. The current employment competition is very fierce. College students should have a sense of crisis in their life, and focus on knowledge supplement and skills strengthening, so that their life is no longer completely derailed from the society. Teachers need from ideas, help students to enhance psychological, enables the students to gradually sure your strengths in the study, recognize my own shortcomings, this process can be divided the growth stage of career planning, different growth stage to focus on teaching, make students have a relatively clear understanding of career. In reality teaching, some colleges and universities do not pay attention to the employment guidance course, so that the students' career planning shows obvious disorder and blindness. Therefore, colleges and universities should improve the employment guidance mechanism of college students according to their own teaching nature, so as to make their career planning efficient and orderly. To be specific, it is necessary to improve the collection system of employment information and cultivate students' practical experience, so that students can understand the actual situation of the post. Career Suggestions can be made to students under fine measurement, objective understanding can be made according to the comprehensive potential of stude nts, and targeted learning can be encouraged. It is necessary to help students to establish a correct career concept, from their own point of view, with self-cognition as the entry point, to establish a correct career view, to help determine career goals, to reduce the situation of blind employment of students [8].

Second, improve the students' vocational curriculum construction, from the curriculum evaluation and curriculum teaching methods to change and innovate, to help students improve their professional ability. The basic learning in college is the learning of professional courses. In the course setting, we should attach importance to the cultivation of college students' career planning ability. Professional mainstream courses need to be paid attention to, but the practical teaching content should not be ignored, which can help to improve students' intrinsic employment quality. The improvement of professional courses can help to cultivate students' professional quality, so that students can better face the actual needs of the future market. The whole teaching should not float on the surface, should sink down, and strengthen the connection between career, application and theory. There should be some innovation in teaching methods, and the curriculum system should be changed on the basis of employment and practical application, so that the teaching content of the curriculum can be expanded from the teaching of knowledge to the teaching of skills or other broader fields. The quality of students' study should also be improved from the study of professional skills to the cultivation of personality quality, so that students can master more professional knowledge on the basis of good personality quality. In the course evaluation system, students should be encouraged to conduct teaching evaluation in the form of employment, and establish standards based on employment, so as to 
help students better grasp the employability, and avoid students continuing to conduct a single quantitative assessment of scores.

Third, take innovation and entrepreneurship as an opportunity to enhance employability. The education of innovation and entrepreneurship can help students to correctly view the employment issue, and also can help to enhance students' ideal pursuit and change their employment concept. In the course education of innovation and entrepreneurship, the main goal should be to stimulate students' learning interest, and to actively build a better platform for students to actively learn knowledge and skills in the context of innovation and entrepreneurship. On the other hand, when students learn innovation and entrepreneurship, they can also have a correct understanding of themselves and view themselves. These drives can be further reflected in students' classroom learning and the cultivation of comprehensive quality, so that students can actively participate in various practices. The school actively builds a school-enterprise cooperation platform to provide students with more abundant resources to help them get in touch with enterprises in advance and better supplement their abilities. The cultivation of university students' employment ability stage, the possible employment goal is not clear, jobs is too single, regions, gender restrictions or awareness of social problems such as not enough clear, colleges and universities to cultivate, should better improve the system of the specific requirements of the employment guidance course and, on the premise of respect for students on career planning of secondary education, enables the students to form correct view of employment, comprehensive their ability to formulate suitable for their own career planning. Schools can also think from the curriculum evaluation and curriculum teaching, more practice, theory, application of three aspects of unified teaching means. We can also start from innovation and entrepreneurship, stimulate students' drive, so as to realize the path to improve students' employability, improve the quality of employment, and achieve stable employment.

\section{REFERENCE}

1. Ren Z, Zeng X. Reform and exploration of civil engineering talents cultivation in applicationoriented universities under the background of "new engineering" $[\mathrm{J}]$. Western quality-oriented education, 2017,17:10-12.

2. Zhang Y. Thinking and practice on the improvement of employability of engineering college students -- a case study of college of automotive engineering, wuhan huaxia university of technology $[\mathrm{J}]$. Modern communication, 2008,490 (20):50-51.

3. Wang L. Analysis on the path to improve college students' scientific and technological innovation ability under the background of the transformation of old and new driving forces $[\mathrm{J}]$. Shandong textile economy, 2018.

4. Zhou G, Wu L. Study on strategies for improving the employability of local application-oriented undergraduates in the new situation $[\mathrm{J}]$. Enterprise technology development, 2008,37(12):114-116.

5. Feng T, Jin-Biao W, Yong-Yao S, Zhao-Ying X, Chao-Zhong G, Yong P. Exploration and practice of "project practice teaching" on improving college students' applied technical ability in the new engineering background -- a case study of metal materials and heat treatment $[\mathrm{J}]$. Education and teaching forum, 2018, 363(21):164-165.

6. Chengji M, Jianghong Y, Tang Y, Qiu X, Zhang Y. Research and exploration on the establishment of innovation and entrepreneurship education center under the background of new engineering to promote the innovation and entrepreneurship capability of applied mechanical talents [J]. Internal combustion engine and accessories, 2008,276(24):247-248.

7. Yang R, Wei L, Xiao-Yan W, Changman X. Research on the training path of college students' innovation and entrepreneurship ability under the background of new engineering -- a case study of mechanical electronics and computer science $[\mathrm{J}]$. College education, 2019, (7).

8. Chao L. Exploration and practice of improving innovation capacity of safety engineering major in $\mathrm{xi}$ 'an university of science and technology from the perspective of new engineering [J]. Coal higher education, 2018, (6):18-21. 